\title{
Removal of Zinc by Bitter Orange Peels Activated Carbon and Commercially Activated Carbon, a Comparison Study.
}

\author{
Asst. Lecturer: Laith Hamdan Hawal \\ Environment Engineering Department, Al-Mustansiryiah University, Baghdad. \\ Laith_hamdaen@yahoo.com
}

\begin{abstract}
:
In this study, a comparison between using activated carbon prepared from bitter orange peels (BOAC) and a common commercially activated carbon (CAC), which is brought from the market, as adsorbent materials. This study was designed to find out which of these two activated carbons is more effective in the removal of zinc from waste water. This work examines the use of bitter orange peels, which are available as waste in local markets and in household garbage as an alternative presage to prepare an activated carbon by using $\left(\mathrm{H}_{2} \mathrm{SO}_{4}\right)$ as activating reagent. The effects of $\mathrm{pH}$, initial zinc concentrations, treatment time, adsorbent media bed height and the flow rate of simulated synthetic aqueous solution (SSAS) on the removal efficiency of zinc were all studied under $24 \mathrm{oC}$

The results indicated that the removal efficiency of zinc increases with decreasing in $\mathrm{pH}$ of SSAS. When the initial concentration of zinc increases in SSAS, the removal efficiency of zinc was decreased. The study proved that the increasing of contact time leads to greater removal efficiency. When the height of adsorbent media in fixed column increases, the removal efficiency was increased. The experiments also showed that the removal efficiency of zinc from the SSAS increased, when the flow rate decreased. It could be concluded from this work that (BOAC) is better than (CAC) as an adsorbent materials in the removal of zinc; with a removal efficiency of $(90 \%, 86 \%)$, respectively
\end{abstract}

Keywords: bitter orange peels, activated carbon, zinc, adsorbent, removal, efficiency.

$$
\text { إزالة الزنك بواسطة الكاريون المنشط المصنع من قثشور النارنج و الكاربون المنشط التجاري, }
$$

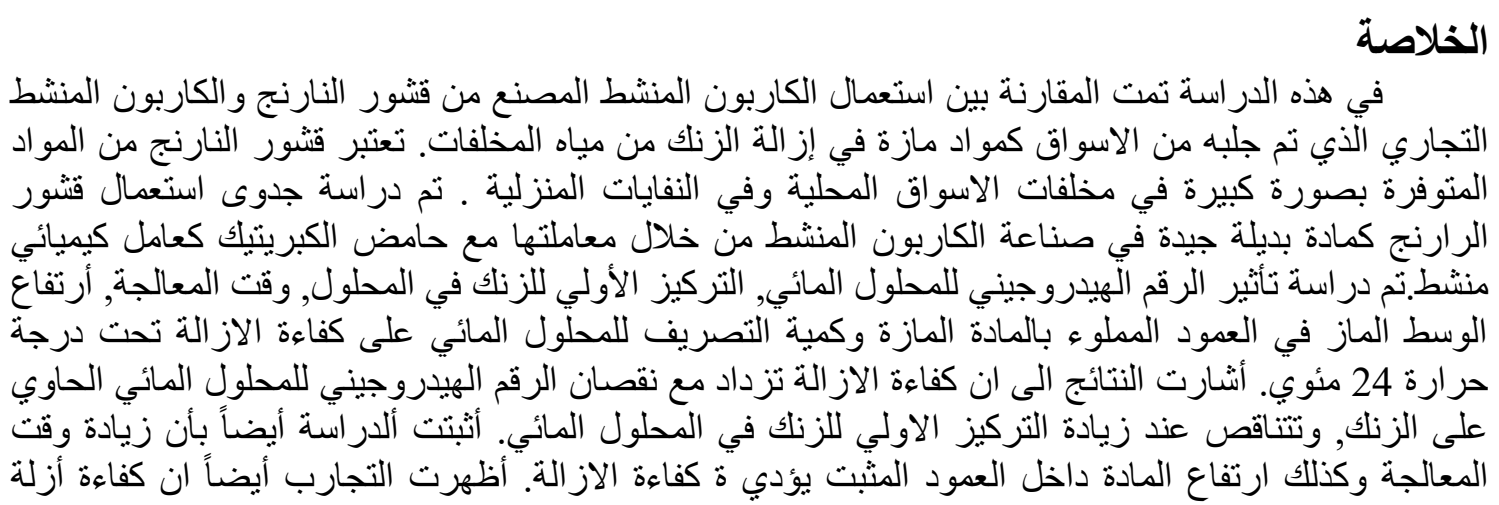




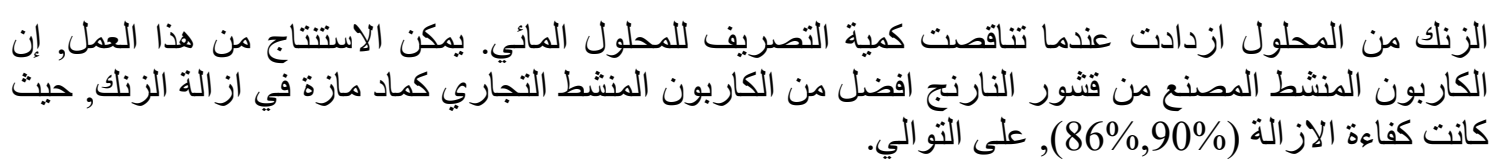

\section{Introduction}

The activities of human in agriculture, industry, transportation and mining...etc have a significant emission and excessive quantities of toxic metal ions are disposed to the environment (soil, water and air). The resulting effluents from smelting, battery manufacturing, metal plating and mining are the main resource of heavy metals in water. Heavy metals like $(\mathrm{Cu}, \mathrm{Cd}, \mathrm{Hg}, \mathrm{Pb}, \mathrm{Ni}$ and $\mathrm{Zn})$ are toxic, non-biodegradable and persevere in the environment. Heavy metals may accumulate in water and soil, and then can cause an adverse effect on organisms [1].

Zinc is one of the most portable heavy metal in groundwater and surface water and it is exist as dissoluble compounds at neutral and acidic $\mathrm{pH}$ values [2]. Zinc is an influential element that is important in human health. When humans absorb so little zinc they can suffer a loss of relish, reduction in the sense of smell and taste, slower fleshwound healing and skin inflammation. Although people can handle properly large concentration of zinc, excessive zinc cause eminent health problems, like skin irritations, stomach cramps, vomiting and nausea. Too high standard of zinc concentrations can damage the pancreas and trouble the protein metabolism. Multitude exposure to zinc chloride can cause troubles in respiratory system. Zinc can be harmful to unborn and newborn children, when their mothers have uptake large quantities of zinc, the children may be exposed to damage of it through milk of their mothers or blood [3]

Membrane filtration, oxidation, damage effects chemical coagulation, solvent extraction and ion exchange have been suggested for the remediation of contaminated water by heavy metals. These operations are efficient in reduction metal contamination risk. Yet, they are costly and restricted to high concentration of heavy metal ions [4]. Adsorption is one of the most appropriate mechanism applied for water treatment, at most because it is appropriate for low concentration of metal ions but it is costly. Adsorption is a physicochemical process whereas the substance called adsorbate collects in the interface of solid called adsorbent. Activated carbon is broadly used as an adsorbent for water treatment because of it has large surface area and porous structure [5]. In spite of its considerable physical characteristics, using activated carbon is limited to its high cost. So, substitutional adsorbents taken from low cost materials should be introduced to reduce the operating cost particularly in developing countries [6]. Low cost adsorbents can be defined as materials plentiful in nature and waste from industries. Many low-cost materials like peanut, fly ash, husk charcoal, used tea leaves, watermelon peels and sunflower leaves have been examined for the removal heavy metals from aqueous solutions [7].

The objective of this study is to manufacture a new alternative activated carbon material (bitter orange peels activated carbon, BOAC) capable of being used as 
adsorbent material in removing heavy metals. This includes a comparison between the manufactured BAOC and a common commercially activated carbon (CAC) as adsorbent material in removing zinc from waste water.

\section{Experimental Work \\ Materials \\ Bitter Orange peels}

Bitter orange peels compounds were investigated by gas chromatography-mass spectrometry (GC-MS) and gas chromatography (GC), while phenolic compounds analyses was executed by invert -phase high performance liquid chromatography (RPHPLC). The limonene was the main volatile compound of bitter orange peels $(90.25 \%)$. HPLC analyses of bitter orange peels showed that phenolic acids compose their main phenolic class represent $(73.80 \%)$, followed by flavonoids $(23.02 \%)$. Ferulic acids and p-Coumaric were the most plentiful phenolic compounds represent $(24.68 \%)$ and $(23.79 \%)$, sequentially in the peels. The antioxidant effectiveness of bitter orange peels have been estimated using four tests in the laboratory, and the results obtained were compared with the typical antioxidants (BHT, BHA, and ascorbic acid). The results showed that Citrus aurantium peels were in possession antioxidant effectiveness which have less efficiency than those of antioxidant standards [8].

\section{Preparation of Bitter orange activated carbon (BOAC)}

Bitter orange peels activated carbon (BOAC) is prepared in a procedure modified from Roopa's work [9]. Bitter orange peels were collected from the waste of a local market in Baghdad. Peels were sun-dried for 7 to 8 days, and then washed two times with distilled water to remove impurities existence. The dried peels were ovendried to remove additional moisture and then crushed and sieved to obtain particles with size $0.5 \mathrm{~mm}$. After that, the peels were transferred into a melting-pot and concentrated $\mathrm{H}_{2} \mathrm{SO}_{4}$ was added and heated by an electrical oven under a temperature ranges between $\left(110\right.$ to $\left.150^{\circ} \mathrm{C}\right)$. Finally, the peels were put under heat of $\left(500^{\circ} \mathrm{C}\right)$ for $(6$ to 8$)$ hours until they were transformed into activated carbon. This chemically activated carbon was put in a beaker and cooled to the room temperature and was washed with distilled water many times, to remove the remaining acid content, then it was dried in hot air oven to evaporate moisture.

The (BOAC) characteristics were measured by the State Company of Geological Survey and Mining, Ministry of Industry and Minerals. The characteristics of the bitter orange peels activated carbon (BOAC) are shown in table (1). 


\section{Commercially activated Carbon (CAC)}

The activated carbon, so called activated charcoal, is a kind of treated carbon that has a large surface area useful in adsorption and other chemical reactions [10]. Granular activated carbon was used immediately without treatment. Activated carbon is oscillator material that can be with positive or negative charge relying on the $\mathrm{pH}$ of solution. The attractiveness between the activated carbon and cationic or anionic guest materials is fundamentally associated with the surface characteristics. Widely negatively charged surfaces are acquired at high $\mathrm{pH}$ values and this favor the uptake of most cationic sets because of decreased electrostatic potential between cations and activated carbon surface and vice versa. An activation grade adequate for beneficial application may be obtained just from high surface area; yet, extra chemical treatment often enhances properties of the adsorption. The characteristics of the commercially activated carbon (CAC) are shown in table (1) [11].

Table (1) Characteristics of Bitter Orange Peels Activated Carbon (BOAC) and Commercially Activated Carbon (CAC)

\begin{tabular}{|c|c|c|c|}
\hline No. & properties & BOAC & CAC \\
\hline 1 & Specific surface area, BET $\left(\mathrm{m}^{2} / \mathrm{g}\right)$ & 1390 & 990 \\
\hline 2 & Grain size $/ \mathrm{mm}$ & 2.9 & 2.2 \\
\hline 3 & Total pore volume $/\left(\mathrm{cm}^{3} / \mathrm{g}\right)$ & 1.98 & 0.9 \\
\hline 4 & Bulk density, $\mathrm{g} / \mathrm{cm}^{3}$ & 0.58 & 0.62 \\
\hline 5 & $\mathrm{pH}$ & 5 & 7 \\
\hline
\end{tabular}

\section{Stock solutions}

To avoid intervention with other materials in wastewater, the tests in this study were accomplished on a simulated synthetic aqueous solution (SSAS) with different zinc concentrations. A zinc stock solution was prepared by dissolving $4.55 \mathrm{~g}$ of $\mathrm{Zn}$ $\left(\mathrm{NO}_{3}\right)_{2} \cdot 6 \mathrm{H}_{2} \mathrm{O}$ powder (Hi Media, Mumbai, India) in $1000 \mathrm{ml}$ of deionized water to achieve $(1000 \mathrm{mg} / \mathrm{l})$. All solutions used in the tests have been prepared by diluting stock solution with distilled water in order to get the desired concentrations for the experiential work of this study. The zinc concentrations in treated water were measured by using spectrophotometer (model Shimadzu AAS-7000).

\section{Adsorption System}

The experiments, of fixed bed column for continuous flow system were conducted in order to examine zinc removal by treating SSAS under many zinc concentration, adsorbent bed depths (bitter orange activated carbon and commercially activated carbon) and various flow rates of SSAS of zinc at various $\mathrm{pH}$. The $\mathrm{pH}$ values were modified using $0.2 \mathrm{~N} \mathrm{NaOH}$ and $0.2 \mathrm{~N} \mathrm{HNO}_{3}$ solutions. Figure (1) shows a 
schematic diagram of the sorption system, where the direction of flow is downwards due to gravity. The sorption system composed of ( 5 liter) plastic container with inlet and another for outlet. Rotameter is a flow meter that measures the flow rate of solution. Glass column has $2.54 \mathrm{~cm}$ ID and height $50 \mathrm{~cm}$. The sorption column filled with adsorbent material to height of $(5,15,25,35$, and $45 \mathrm{~cm})$. The filled bed sorption column was washed by distilled water twice down flow through the column before starting the runs.

The adsorbent media (CAC and BAOC) were packed in the column to the desired depth, and fed to it as slurry by mixing up the sorption media with distilled water to avoid formation of air bubbles in the media. The adsorption process started by allowing the SSAS of required zinc concentration and $\mathrm{pH}$, to flow downwards by gravity through the sorption column at a precise flow rate $(1 \mathrm{l} / \mathrm{min})$, as shown in figure (1). To determination the best operational conditions, the tests were executed at a constant temperature $\left(24^{\circ} \mathrm{C}\right)$ and different $\mathrm{pH}$ values (between 1-9), initial feed concentrations of zinc (between 1-80 mg/l), treatment time (between 15-120 min), adsorbent bed height (between $5-45 \mathrm{~cm}$ ) and flow rates (between $5-50 \mathrm{ml} / \mathrm{min}$ ). Water samples, after treatment in each test, were collected every 15 minutes from the bottom of packed column and the adsorbed concentration of zinc ion in SSAS was determined by spectrophotometer. Table (2) shows the conditions of all experiments.

Table (2) Conditions of the experiments

\begin{tabular}{|c|c|c|c|c|c|c|}
\hline $\begin{array}{c}\text { EX. } \\
\text { NO. }\end{array}$ & $\begin{array}{c}\text { Initial } \\
\text { zinc } \\
\text { conc. } \\
(\mathrm{mg} / \mathrm{l})\end{array}$ & $\begin{array}{c}\mathrm{pH} \text { of } \\
\text { SSAS }\end{array}$ & $\begin{array}{c}\text { Treatment } \\
\text { time } \\
(\mathrm{min})\end{array}$ & $\begin{array}{c}\text { Adsorbent } \\
\text { media bed } \\
\text { height } \\
(\mathrm{cm})\end{array}$ & $\begin{array}{c}\text { Flow } \\
\text { rate } \\
(\mathrm{ml} / \mathrm{min})\end{array}$ & $\begin{array}{c}\text { Purpose of } \\
\text { Exp. }\end{array}$ \\
\hline EX-1 & $1-80$ & 1 & 120 & 45 & 5 & $\begin{array}{c}\text { Effect of } \\
\text { initial } \\
\text { concentration }\end{array}$ \\
\hline EX-2 & 1 & $1-9$ & 120 & 45 & 5 & $\begin{array}{c}\text { Effect of } \\
\text { SSAS pH }\end{array}$ \\
\hline EX-3 & 1 & 1 & $15-120$ & 45 & 5 & $\begin{array}{c}\text { Effect of } \\
\text { treatment } \\
\text { time }\end{array}$ \\
\hline EX-4 & 1 & 1 & 120 & $5-45$ & 5 & $\begin{array}{c}\text { Effect of the } \\
\text { adsorbent } \\
\text { media bed } \\
\text { height }\end{array}$ \\
\hline EX-5 & 1 & 1 & 120 & 45 & $5-50$ & $\begin{array}{c}\text { Effect of } \\
\text { SSAS flow } \\
\text { rate }\end{array}$ \\
\hline
\end{tabular}




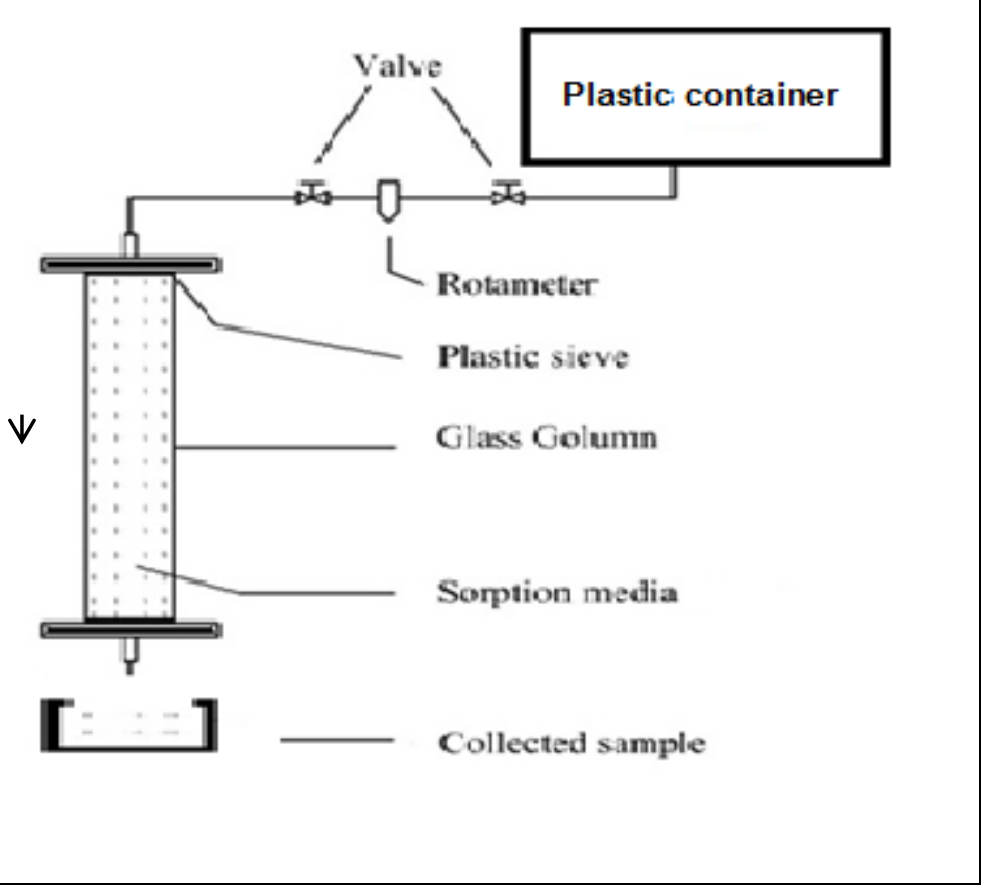

Figure (1) Schematic diagram of the adsorption system

\section{Results and Discussions}

The experiments of removing zinc from SSAS is achieved by fixed bed column and executed under continuous system with different parameters, which are initial concentrations $\left(\mathrm{C}_{\mathrm{o}}\right)$ of zinc in SASS, $\mathrm{pH}$ of SSAS, time of treatment $(\mathrm{t})$, bed height of adsorbent media $(\mathrm{h})$ and the flow rate of SSAS (Q). The experiments were executed under a temperature of $24^{\circ} \mathrm{C}$ ( $\mathrm{T}$ (feed)). The removal efficiency of zinc from SSAS is calculated by the following equation:

$$
\mathrm{R}(\%)=\frac{\text { Initial conc. }- \text { Residual conc. }}{\text { Initial conc. }} * 100
$$

Where:

R: Removal Efficiency 


\section{Effect of Initial Concentration}

Figure (2) shows that the removal efficiency of zinc is decreasing when the initial zinc concentration $\left(C_{\mathrm{o}}\right)$ in SSAS increased (at $\mathrm{T}_{\text {(feed) }}$ of $24^{\circ} \mathrm{C}$, h of $45 \mathrm{~cm}, \mathrm{pH}$ of 1 , $\mathrm{t}$ of $120 \mathrm{~min}$ and $\mathrm{Q}$ of $5 \mathrm{ml} / \mathrm{min}$ ). This can be explained by the reality that the initial concentration of zinc had a limited impact on zinc removal capacity; at the same time, the adsorbent media had a restricted number of active places, which would have become appeased at a definite concentration. This leads to an increase in the number of zinc molecules contending for the available functions places on the surface of adsorbent material. As the solution of lower concentration has a small concentration of zinc than the solution of higher concentration of it, then the zinc removal efficiency was decreased with increasing initial zinc concentration in solution [12]. When bitter orange peels activated carbon (BOAC) is used, higher efficiency for zinc removal (reached $90 \%)$ at initial concentration of zinc in solution $(1 \mathrm{mg} / \mathrm{l})$ under the same other parameters; compared with $(86 \%)$ removal efficiency when the commercially activated carbon (CAC) was used. This means that (BOAC) was efficient and was better than the commercially activated carbon in removing zinc from SSAS.

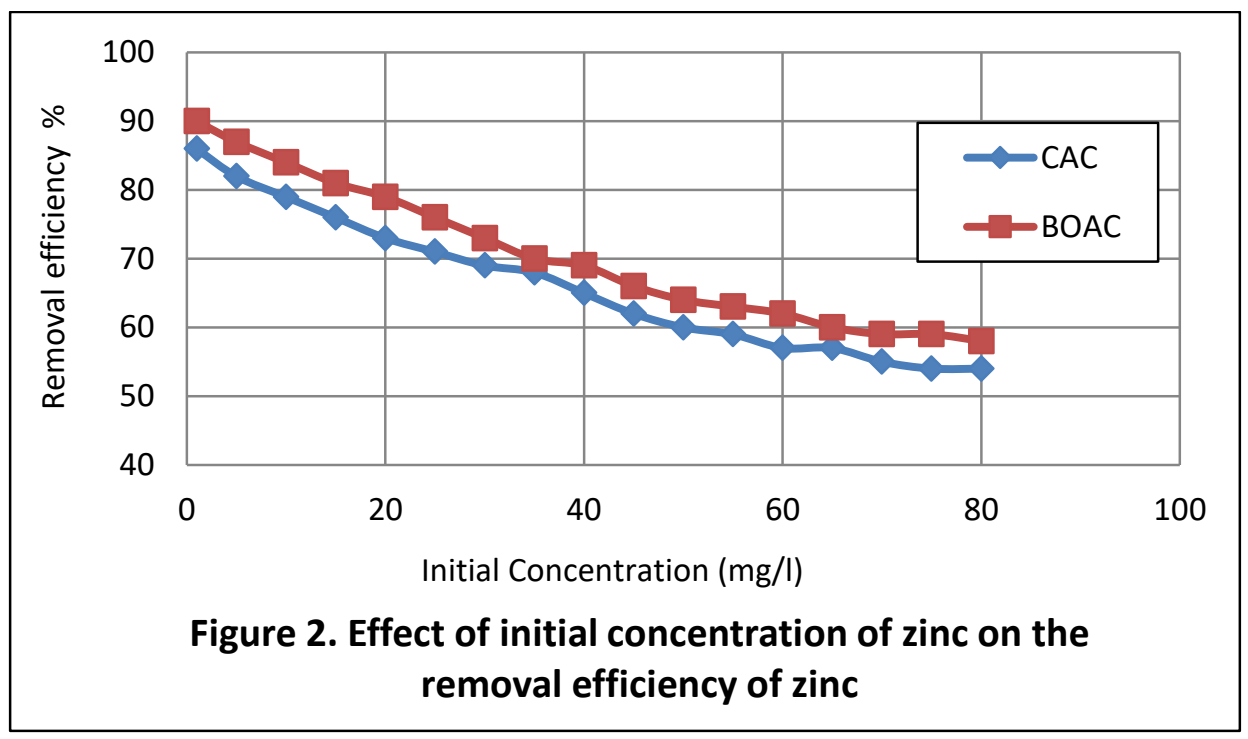

\section{Effect of SSAS pH}

Figure (3) shows the increasing in the removal efficiency of zinc when the $\mathrm{pH}$ of SSAS decreased from 9 to 1 (at $\mathrm{C}_{\circ}$ of $1 \mathrm{mg} / \mathrm{l}$, Q of $5 \mathrm{ml} / \mathrm{min}, \mathrm{T}_{\text {(feed) }}$ of $24^{\circ} \mathrm{C}$, h of $45 \mathrm{~cm}$ and $\mathrm{t}$ of $120 \mathrm{~min}$ ). The increasing in removal efficiency can be related to the following: The adsorption of zinc from aqueous solution is dependent on the $\mathrm{pH}$ of the solution, which affect the surface charge of the adsorbent, and the degree of ionization and speciation of the adsorbate species. This could be due to the depending of zinc 
ionization on the $\mathrm{pH}$ value. Zinc may be adsorbed to a lowest extent at higher $\mathrm{pH}$ values due to the impulsive force prevalent at higher $\mathrm{pH}$ values. In addition and in the higher $\mathrm{pH}$ values, zinc might forms salts which readily ionize leaving negative charge on the zinc ion [12]. Together, the presence of $\mathrm{OH}$ - ions on the adsorbent prevents the uptake of zinc ions. $\mathrm{pH}$ also effect on the surface properties of the sorbent, i.e., charge of the surface of the cells used as sorbent. At very low $\mathrm{pH}$ values, the surface of the sorbent would also be surrounded by the hydronium ions, which reinforce the zinc interaction with binding places of the sorbent by greater attractive forces, thus its intake on polar adsorbent is reduced [13]. It should be noted however, that BAOC has better (90\%) than $\mathrm{CAC}$ because it already has less $\mathrm{pH}$ than $\mathrm{CAC}$ (5 and 7, respectively, table 1.), which may make it more efficient than $\mathrm{CAC}$ in zinc removal.

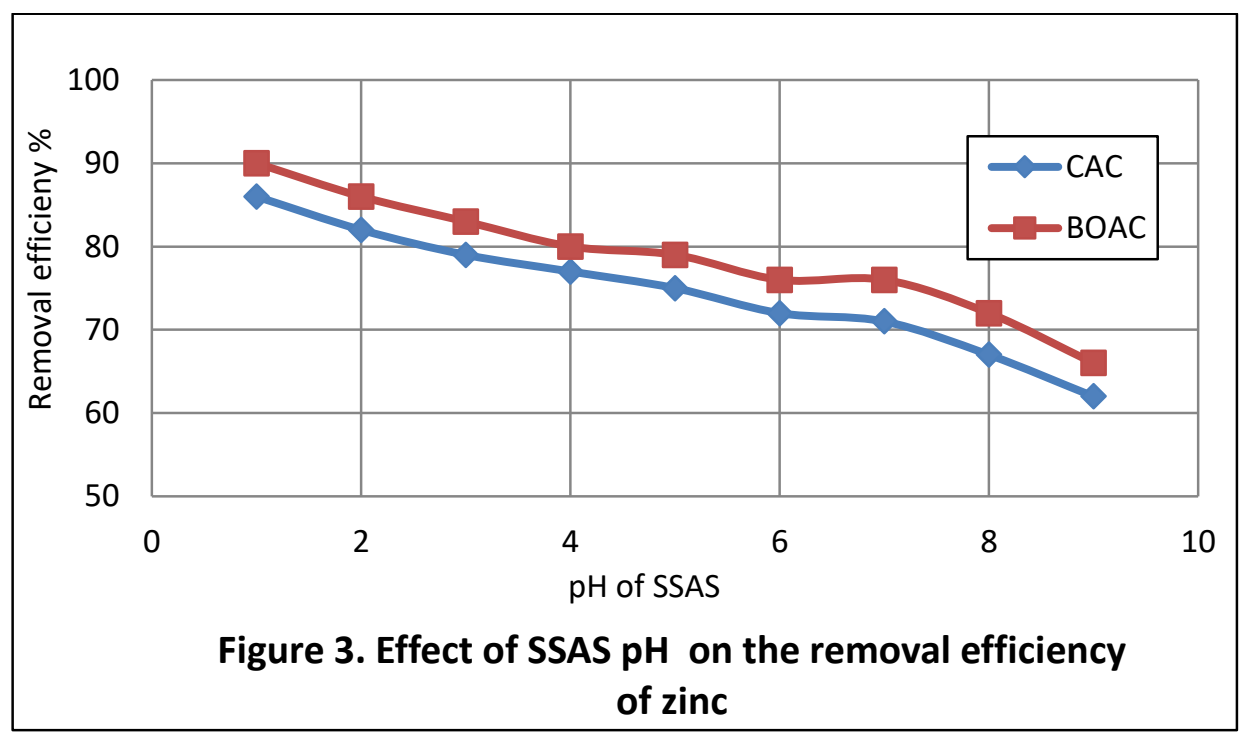

\section{Effect of Treatment Time}

Figure (4) shows that when the treatment time of SSAS increased, the removal efficiency of zinc was also increased (at $\mathrm{C}_{\text {。 }}$ of $1 \mathrm{mg} / \mathrm{l}$, Q of $5 \mathrm{ml} / \mathrm{min}, \mathrm{T}_{\text {(feed) }}$ of $24^{\circ} \mathrm{C}, \mathrm{h}$ of $45 \mathrm{~cm}$ and $\mathrm{pH}$ of 1). This result may be due to the fact that when treatment time is increased, SSAS will take longer time in contact with adsorbent materials (BOAC and $\mathrm{CAC}$ ). Hence the adsorbent material adsorbs more quantity of zinc and therefore better removal efficiency [14]. However, BOAC has shown greater efficiency in removing zinc. 


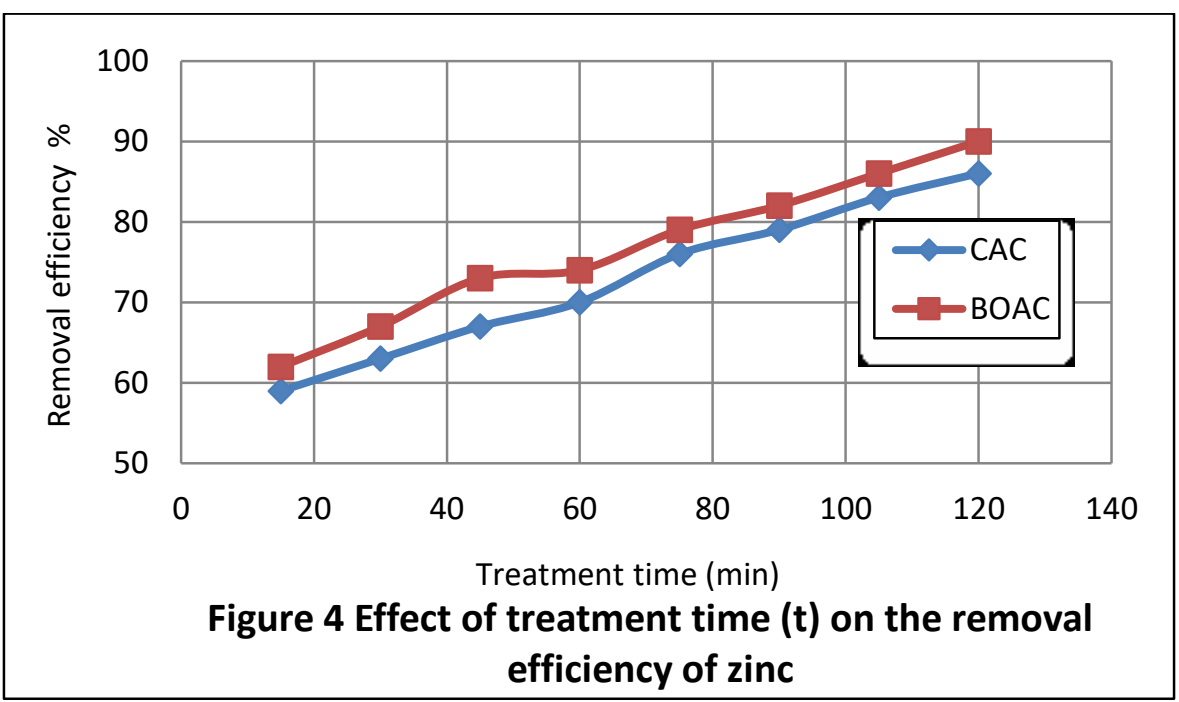

\section{Effect of the Adsorbent Media Bed Height}

Figure (5) shows that when the height of adsorbent media bed increased, the removal efficiency of zinc was also increased (at $\mathrm{C}_{\text {。 }}$ of $1 \mathrm{mg} / \mathrm{l}$, Q of $5 \mathrm{ml} / \mathrm{min}, \mathrm{T}_{\text {(feed }}$ ) of $24^{\circ} \mathrm{C}$, pH of 1 , and $\mathrm{t}$ of $120 \mathrm{~min}$ ). The increasing of bed height (h) means increasing in the quantity of adsorbent media and this may increase the surface area, the number of active places on the adsorbent material surface, the availability of binding sites for adsorption and thus increase the capacity of zinc removal on adsorbent media [14]. This leads to the capability of the adsorbent media to adsorb largest quantity of zinc from SSAS at low initial concentrations and hence increasing the removal efficiency of zinc. Once again, (BAOC) has shown greater ability in removing zinc than (CAC).

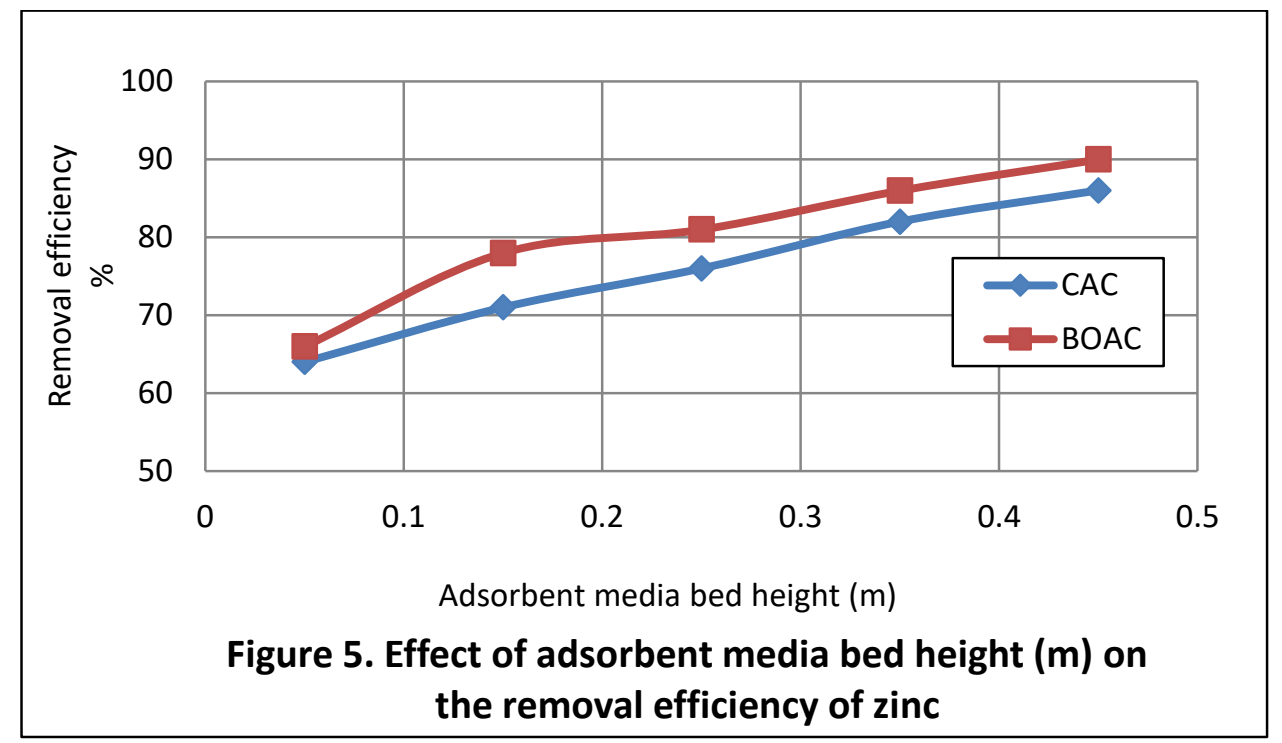




\section{Effect of SSAS flow rate}

Figure (6) shows the relation between the flow rate SSAS and the removal efficiency of zinc. The results proved that increasing of flow rate means a decreasing in the removal efficiency of zinc from SSAS (at $\mathrm{C}_{\circ}$ of $1 \mathrm{mg} / 1$, $\mathrm{T}$ (feed) of $24^{\circ} \mathrm{C}, \mathrm{pH}$ of 1 , and $t$ of $120 \mathrm{~min}$ ). When the flow rate is increasing, the velocity of SSAS flows in the fixed bed column increasing also. This means that the contact time of SSAS with adsorbent media in the column is decreasing, and then the adsorbent materials may uptake a lower amount of zinc from SSAS. Therefore the removal efficiency of zinc was decreased. While when the flow rate is decreased, the opposite will happen and the removal efficiency of zinc is increased [14]. Noticeably, BAOC appears to have greater ability in removing zinc than $\mathrm{CAC}$.

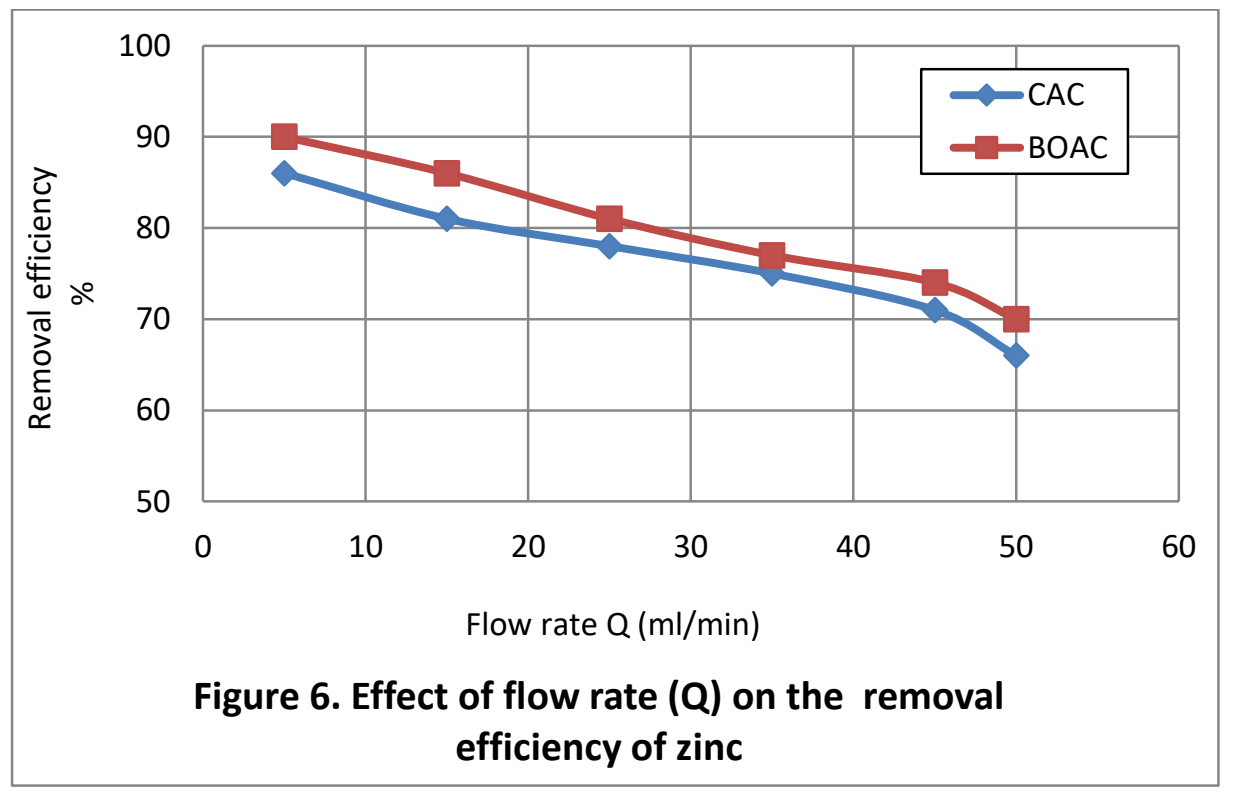

\section{Conclusions}

1. The removal efficiency of zinc by using (BOAC and AACA) was increased with the decreasing of initial concentration of zinc, $\mathrm{pH}$ of solution and flow rate. While the removal efficiency was increased with the increasing of both height of adsorbent material and treatment time.

2. The study proved that the prepared bitter orange peels activated carbon (BOAC) is better than the commercially activated carbon (CAC) as an adsorbent material to remove heavy metals from waste water $(90 \%$ and $86 \%$ for $\mathrm{BAOC}$ and $\mathrm{CAC}$, respectively); because (BOAC) possesses greater specific surface area, lower $\mathrm{pH}$, superior mechanical resistance and potential to adsorb harmful contaminants than (CAC). 
3. The manufactured bitter orange activated carbon (BOAC) showed a good capability in removing zinc from SSAS by using a fixed bed adsorption system. So, (BAOC) is recommended to remove heavy metals from wastewater. In addition, bitter orange peels are available, a low cost and do not cause any damage to the environment. However, (BAOC) is cheaper than CAC, simple in use and has a high capability to adsorb heavy metals.

\section{References}

(1) Kumar, K.Y., Muralidhara, H.B., Nayaka, Y.A., Balasubramanyam, J. and Hanumanthappa, H. 2013, "Low-Cost Synthesis of Metal Oxide Nanoparticles and Their Application in Adsorption of Commercial Dye and Heavy Metal Ion in Aqueous Solution", Powder Technology, 246, 125-136.

(2) Evanko and Dzombak, 1997, "Remediation of metals-contaminated soils and groundwater". Technology evaluation report, "Gound-Water Remediation Technologies Analysis Center", Pittsburgh University, EPA. TE-97-01.

(3) Lenntech BV Rotterdamseweg. 2017, "Chemical properties of zinc - Health effects of zinc - Environmental effects of zinc", Rotterdamseweg 402 M 2629 HH Delft.

(4) Ngah, W.S.W. and Hanafiah, M.A.K.M., 2008, "Removal of Heavy Metal Ions from Wastewater by Chemically Modified Plant Wastes as Adsorbents", Review.BioresourceTechnology.99, 3935-3948.

(5) Bhatnagar, A. and Sillanpää, M, 2010, "Utilization of Agro-Industrial and Municipal Waste Materials as Potential Adsorbentsfor Water Treatment", A Review. Chemical Engineering Journal, 157, 277-296.

(6) Banerjee, K., Ramesh, S.T., Gandhimathi, R., Nidheesh, P.V. and Bharathi, K.S. 2012, "A Novel Agricultural Waste Adsorbent, Watermelon Shell for the Removal of Copper from Aqueous Solutions" Iranica Journal of Energy and Environment, 3, 143-156.

(7) Benaïssa, H. and Elouchdi, M.A, 2008, "Removal of Copper Ions from Aqueous Solutions by Dried Sunflower Leaves", Chemical Engineering and Processing, 46, 614-622.

(8) Jabri Karoui I, Marzouk B, 2013, "Characterization of bioactive compounds in Tunisian bitter orange (Citrus aurantium L.) Peels and juice and determination of their antioxidant activities", US National Library of Medicine National Institutes of Health. Biomed Res Int.; 2013:345415. doi: 10.1155/2013/345415.

(9) Roopa.D, 2016, "Preparation of Bitter orange activated carbon (Citrus Aurantium) and Preliminary Studies on Its Characteristics", International Journal of Scientific \& Engineering Research, Volume 7, Issue 4, April- 40 ISSN 2229-5518.

(10)CPL Caron Link, 2014, "Properties of Activated Carbon", accessed 2008-05-02". Retrieved 13 October. 
(11) R.-L. Tseng, S.-K. Tseng, F.-C. Wu, C.-C. Hu and C.-C. Wang, 2008, "Effects of micro pore development on the physicochemical properties of $\mathrm{KOH}$-activated carbons", Journal of the Chinese Institute of Chemical Engineers, vol. 39, no. 1, pp. $37-47$.

(12) Urbain Kouakou, Aimé Serge Ello, Jacques Aboua Yapo and Albert Trokourey, 2013, "Adsorption of iron and zinc on commercial activated carbon", Laboratoire de Chimie Physique, Université Félix Houphouët Boigny, Journal of Environmental Chemistry and Ecotoxicology, Accepted 20 May.

(13) Kermani, M., Pourmoghaddas, H., Bina, B., and Khazaei, Z., 2009, "Removal of Copper from Aqueous solutions by Rice Husk Ash and Activated Carbon", Pakistan Journal of Biological Science 9 (10): 1905-1910, ISSN 1028-8880.

(14) Muataz Ali Atieh, 2011, " Removal of Zinc from Water Using Modified and NonModified Carbon Nano fibers", Chemical Engineering Department Center of Research Excellence in Nanotechnology (CENT) King Fahd University of Petroleum \& Minerals, KSA, 2nd International Conference on Environmental Science and Technology IPCBEE, IACSIT Press, Singapore. vol.6. 